Article

\title{
Renovation of Public Buildings towards nZEB: A Case Study of a Nursing Home
}

\author{
Mihaela Teni *(1), Ksenija Čulo® and Hrvoje Krstić \\ Faculty of Civil Engineering and Architecture Osijek, Josip Juraj Strossmayer University of Osijek, Vladimira \\ Preloga 3, 31000 Osijek, Croatia \\ * Correspondence: mteni@gfos.hr; Tel.: +385-912-240-826
}

Received: 15 May 2019; Accepted: 24 June 2019; Published: 26 June 2019

\begin{abstract}
Recently, the European Union set new rules for the Energy Performance of Buildings emphasizing the need to facilitate the cost-effective renovation of existing buildings into nearly zero-energy buildings (nZEB). Within this framework, the aim of this paper is to investigate and evaluate the energy performance of existing public buildings before and after renovation into nearly zero-energy buildings. Since the general quality of existing buildings in Croatia has changed over different periods of construction, the presented research was conducted on a representative nursing home designed corresponding to different Croatian national building stock construction periods, based on a public sector buildings database obtained from the Croatian Energy Management Information System (EMIS). The thermal performance of the building envelope was designed to correspond to the periods of buildings built up to 1940, between 1941 and 1970, and between 1971 and 1980, taking into account characteristic building construction technology and service life. In terms of adopted energy efficiency measures, for all nearly zero-energy building renovation solutions, an energy and cost analysis was performed. The results showed that construction technology applied in different construction periods has the greatest impact on the energy performance of a building and thus on the economic and financial viability of investment in nZEB.
\end{abstract}

Keywords: nearly zero-energy buildings; energy management information system; building construction technology; cost-energy analysis; service life

\section{Introduction}

The main issues of building stock within the European Union (EU) are vast energy consumption and greenhouse gas emissions [1]. More specifically, in the EU, the building sector is responsible for approximately $40 \%$ of energy consumption and $36 \%$ of $\mathrm{CO}_{2}$ emissions [1,2]. The majority of these buildings were constructed up to 1980; thus, 35\% of the existing buildings are over 50 years old and $75 \%$ of the building stock is energy inefficient [3]. This issue is even greater, since $75-90 \%$ of existing buildings are expected to be standing in 2050, while more than one-quarter of 2050's projected building stock is still to be built [3].

Therefore, when it comes to new and existing buildings, energy efficiency requirements are becoming more and more stringent. Regarding new buildings, the European Directive on the Energy Performance of Buildings (EPBD) 2010/31/EU prescribes that all new public buildings constructed after 2018 shall be nearly zero-energy buildings (nZEB) while after 2020 the same shall apply for all newly built residential buildings [1]. On the other hand, existing energy-inefficient buildings, which are often inadequately heated and consume-and will continue to consume-great amounts of energy unless renovated in terms of their energy performance as soon as possible, represent a far greater challenge. This issue was revised in the Energy Performance of Buildings Directive 2018/844/EU, which sets a framework aiming at the long-term renovation of existing building stock and decarbonization by 2050 [2]. 
Under the directive, all member states of the EU must devise the long-term renovation strategies by linking policy and financing that will render their building stock nearly zero-energy by 2050 .

In Europe, the nearly zero-energy standard was introduced in the building sector eight years ago. Since then, all European member states have been working on the implementation of the EPBD nZEB requirements and research activities have mainly been focused on the investigation of appropriate and reasonable technological solutions for nZEB design [4-9]. The nearly zero-energy concept aims at designing highly energy efficient sustainable buildings and improving existing buildings in terms of energy efficiency and renewable energy. Considering renewable energy, the aforementioned directive defines that the low or nearly zero-energy demand of nZEB should be covered to a considerable extent by renewable sources produced on-site or nearby [1]. Each member state should define their own parameters for the characterization of nZEB reflecting their national, regional, or local conditions, including a numerical indicator of primary energy use expressed in $\mathrm{kWh} / \mathrm{m}^{2}$ per year [1]. In Croatian regulations, minimum energy performance requirements to achieve nZEB refer to the consumption of primary energy for heating, cooling, ventilation, hot water supply, and lighting, as well as specific annual energy needs for heating and thermal transmittance values of building envelope elements [10]. Regarding renewable energy implementation, a minimum of 30\% integration of renewable energy sources to meet the energy needs of the building is required at the national level. According to this regulation, in the case of a deep renovation of an existing building, it is necessary to apply highly efficient alternative systems and to introduce intelligent measuring systems to ensure that the renovations are technically, functionally, and economically feasible, based on the calculations and cost optimization analysis.

Considering the nZEB policy, it is important to improve the thermal performance of the building envelope. In the literature, the potential of technical retrofits, including the replacement of a building's physical components with more efficient ones, has been studied extensively [11,12]. Several authors investigated the role of the building envelope and its optimization through models and energy simulations in different climate zones in nZEB design [13-15] as well as the energy renovation of existing building stock towards nearly zero-energy [16-20]. Studies dealing with the thermal characterization of the building envelope have shown that the evaluation of the actual thermal performance of a building envelope is an important step for the energy consumption diagnosis since building envelope design can significantly reduce the energy consumption of a building [13,21-24]. The building envelope directly affects energy consumption and the building's thermal performance. However, building envelope characteristics are dependent on the period in which the envelope was made, since that period determines applied building technology. Moreover, each period is characterized by different legislation regarding restrictions of building envelope thermal properties. Aside from technical retrofits, 'human-based retrofits' present an alternative that refers to actions taken by building occupants or facility managers to improve building energy performance through more efficient and rational systems operation $[25,26]$. Human-based retrofits come with very low or no implementation costs and have no effect on the comfort and wellbeing of building occupants [27]. Recent studies assessed the economical and energy benefits of such retrofits, showing a significant potential for energy savings up to $20 \%$ of the building's total energy consumption through the application of measures such as energy-efficient HVAC temperature setpoints $[28,29]$ and adjusting thermostat setpoint temperatures or minimizing the use of equipment and lighting afterhours [30].

Since the general quality of existing buildings in Croatia varies according to different periods of construction as a result of different climatic, technical/technological, economic, legislative, and sociological impacts, it is important to analyse buildings according to the construction period and corresponding building technology when conducting energy renovation in order to reach the nZEB level. Furthermore, buildings constructed in periods of construction expansion, i.e., until 1980, are already more than 38 years old, which highlights the need to perform energy performance and cost analyses taking into consideration building age, service life, energy savings, and payback periods. 
This paper aims to present possible nZEB renovation solutions for a public building, i.e., a nursing home, in terms of energy performance and cost analyses. A representative nursing home, obtained from the Croatian Energy Management Information System (EMIS), was analysed and varied according to Croatian national building stock classifications through different construction periods. The majority of existing public buildings were built in the first three periods of construction, i.e., until 1980, and these buildings have the highest annual thermal energy requirements. Therefore, in terms of year of construction and share of public units according to year of construction, the analysed building was designed to correspond to periods of buildings built until 1940, between 1941 and 1970, and between 1971 and 1980. The presented results give information about renovation costs, energy consumption reduction, and payback periods for proposed renovation measures applied to achieve the nZEB level in relation to the predicted service life of building components and building age. In Table 1, a list of the nomenclature used in this paper is presented.

Table 1. Nomenclature.

\begin{tabular}{ccc}
\hline $\mathrm{A}_{\mathrm{k}}$ & Useful surface area of the building (net area) & $\mathrm{m}^{2}$ \\
\hline $\mathrm{A}$ & Heated surface area of the building envelope & $\mathrm{m}^{2}$ \\
\hline $\mathrm{V}_{\mathrm{e}}$ & Heated volume of the building & $\mathrm{m}^{3}$ \\
\hline $\mathrm{f}_{0}$ & Building shape factor & $\mathrm{m}^{-1}$ \\
\hline $\mathrm{E}_{\text {prim }}$ & Specific annual primary energy & $\mathrm{kWh} /\left(\mathrm{m}^{2} \mathrm{a}\right)$ \\
\hline $\mathrm{Q}^{\prime \prime} \mathrm{H}$, nd & $\begin{array}{c}\text { Specific annual energy demands for heating } \\
\text { for referential climatic data }\end{array}$ & $\mathrm{kWh} /\left(\mathrm{m}^{2} \mathrm{a}\right)$ \\
\hline
\end{tabular}

\section{Representative Public Building Design: A Case Study}

The main characteristic of existing building stock is irrationally high energy consumption. In 2016, in Croatia, the share of energy consumption in buildings was 43.85\% [31]. It is estimated that almost $50 \%$ of the building stock was built before 1970, i.e., prior to the adoption of the first regulation on thermal protection of buildings (Figure 1) [32]. The problem of these buildings, built prior to the adoption of the first regulations on thermal protection of buildings and even those built up until 1987, is that such buildings have poor energy performance and are characterized by the absence or modest application of thermal insulation. Furthermore, buildings built prior to 1987, which make up $78 \%$ of the total building stock (Figure 1) also show the highest annual thermal energy requirements for heating, cooling, domestic hot water (DHW) generation, and lighting [32]. According to previous studies, these buildings consume between 230 and $250 \mathrm{kWh} / \mathrm{m}^{2}$ of useful energy for heating [32,33]. Since these buildings will continue to be used for many more years, it is, from a long-term perspective, important to ensure that these buildings are deeply renovated in terms of energy efficiency and in accordance with current regulations.

Large energy consumption in buildings is mostly related to the construction period. The construction period has an important role in buildings' energy demand since it is related to and represents characteristic construction technology, characteristic building materials used, and the legislation on thermal protection of buildings at the time. In Croatia, buildings are classified into seven construction periods according to the age and type of construction and depending on the legislative environment [32] (Figure 1).

A representative nursing home for the energy performance calculations of renovation toward the nZEB level was obtained from the Croatian Energy Management Information System (EMIS). EMIS is a web application for energy source consumption monitoring and analysis in public sector buildings $[34,35]$. The EMIS database comprises over 3500 public sector buildings and contains static technical data of each facility including general, construction, and energy performance data as well as dynamic energy resource usage data. 
For the purpose of this study, from the EMIS database, construction periods comparable to those at the national level were determined after database cleansing using the algorithm that was proposed in our previous paper based on possible range of variables and the replacement of invalid input values [36]. The research results on database cleansing provided a systematic approach to determining the possible range of buildings' constructional characteristics. Before this research, there was no literature that systematically covered issues regarding possible values of building constructional characteristics, especially variables such as the building shape factor, share of windows surfaces, and thermal transmittance coefficient (U-value). An algorithm for the constructional characteristics data cleansing of large-scale public building databases was proposed, along with a procedure for the replacement of invalid and/or missing input values. Based on the research results, a flowchart describing the algorithm for constructional characteristics data cleansing of large-scale public building databases was created.

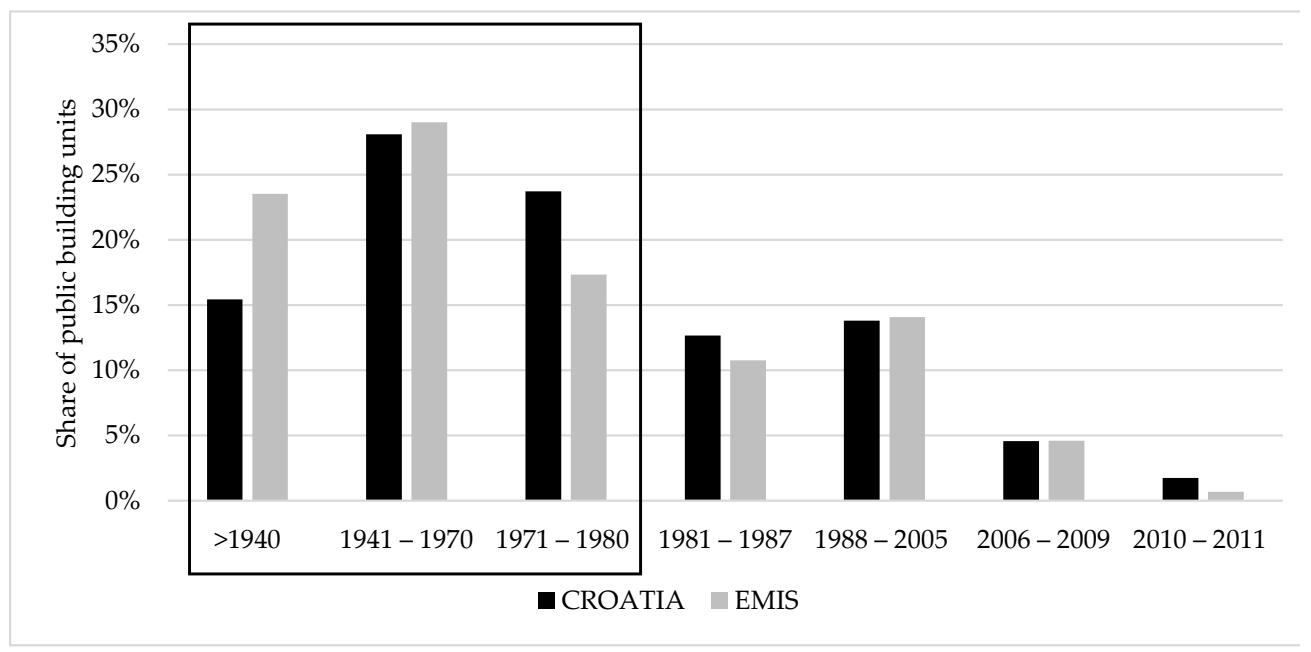

Figure 1. Share of public building units in Croatia and in the Energy Management Information System (EMIS) database according to the year of construction.

Based on the research briefly presented above, we were able to select a representative nursing home from the EMIS database for which all constructional characteristics were possible and without user input errors. Further, the proposed cleansing algorithm can be used to do the same for all other types of buildings and constructional characteristics in the database. The corresponding shares of public units by the year of construction are shown in Figure 1. It can be seen that shares of public units according to the year of construction are proportionate. The majority of existing public buildings were built in the first three periods of construction, i.e., until 1980 (Figure 1). Since it has been shown that these buildings have the highest annual thermal energy requirements, it is important to perform a deep renovation of these buildings. However, buildings constructed in the first three periods of construction, which make up approximately $70 \%$ of the total building stock, are already more than 38 years old and, in worst-case scenarios, more than 78 years old. It is therefore crucial to analyse and clarify the investment costs for the renovation of these buildings into nZEB, taking into consideration building age, energy savings, and payback periods. In order to clarify these issues, taking into account that fact that the majority of public buildings were built before 1980, energy and cost analyses were performed for the first three construction periods.

Basic data information about public buildings from the EMIS database-including building technology, age, climatic data, building size, number of floors, and thermal properties of different construction parts of buildings - was analysed in order to determine a representative public building for each period studied. Detailed descriptive statistics of building characteristics of public buildings from the EMIS dataset were presented in our previous research [37]. This analysis [37] showed that, according to climatic zones, the majority of buildings from the database are located in the continental part of Croatia. This finding is the same as the results obtained at the national level [32]. 
Since the majority of the heat losses occur through external walls and the thermal insulation of external walls represents the most commonly used measure when performing energy renovations, the U-values of walls contained in the database were analysed in greater detail and compared with characteristic $U$-values for the first three periods of construction for the continental part of Croatia (Figure 2). At this point, the maximum value of the thermal transmittance coefficient (U-value) that must be met for external walls is set to $0.30 \mathrm{~W} / \mathrm{m}^{2} \mathrm{~K}$ for the continental part of Croatia, where an average monthly air temperature of the coldest month is less than or equal to $3{ }^{\circ} \mathrm{C}$ [10]. As can be seen from Figure 2, characteristic U-values at the national level are somewhat higher compared to the values obtained as an average from the EMIS database for each construction period. The following can be explained by the fact that some of the buildings in the database have been partly renovated in the past. Furthermore, the number of valid samples varies depending on the construction period analysed, since all buildings may not have the same construction materials due to user negligence [37]. However, there is a general lack of valid entries of U-values in the database, preventing it from being considered as representative of the national building stock. Furthermore, the average U-values from the database, though they are lower than characteristic values of the national stock, do not meet the minimum energy performance requirements of the current legislation. Hence, further analysis relies on characteristic U-values of building elements defined at the national level.

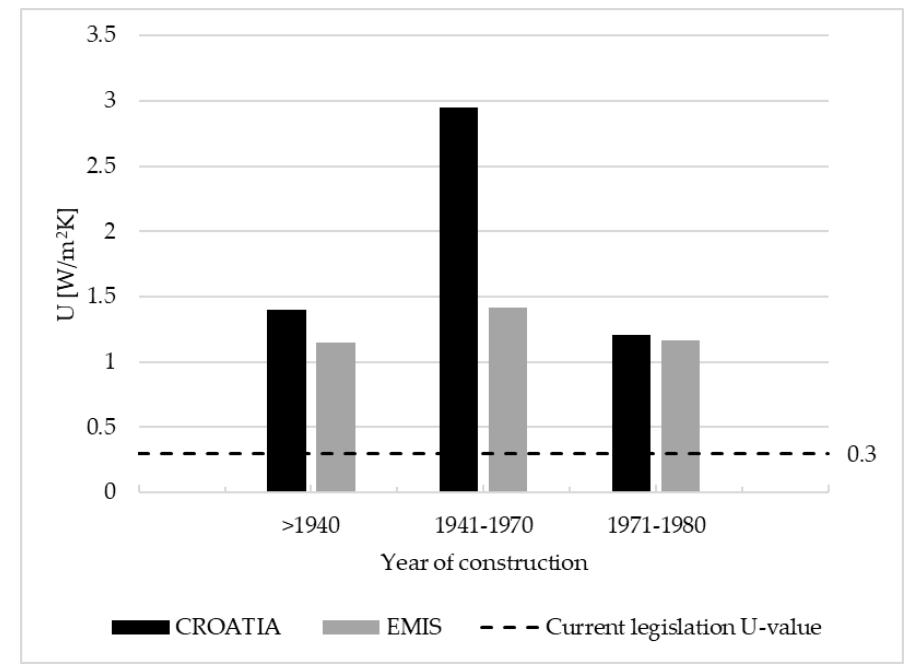

Figure 2. Characteristic U-values for external walls according to the year of construction.

After the detailed analysis of the database, a typical nursing home building located in the continental part of Croatia was chosen from the EMIS database from the period of construction that comprises the largest number of buildings. The thermal properties of different construction parts of the analysed building were designed to correspond to the periods of buildings built until 1940, between 1941 and 1970, and between 1971 and 1980. Therefore, three case studies were employed in the analysis with a fixed geometry but with different thermal characteristics and envelope qualities in order to make them comparable for analysis. The main characteristics of the case studies, each taken as a representative of the building stock of the three abovementioned periods, are shown in Table 2 . The analysed building is a three-story nursing home with a total area of $1100 \mathrm{~m}^{2}$. In the initial state, in all three case studies, the building had natural ventilation and a centralized heating system that utilized gas as an energy source.

Building A was designed as a representative of the period of construction prior to 1940 - a full-brick masonry structure with a brick floor, wooden ceiling, wooden inclined roof, and wooden double single-glazed windows.

Building B represents the period of construction from 1941 to 1970. This period is characterized by poorer thermal performance compared to the previous period due to the early application of new materials, 
mostly reinforced concrete, resulting in thinner structural elements and major thermal losses. Building B was designed as a reinforced concrete structure with a flat roof and single-glazed wooden windows.

Table 2. The main characteristics of the case studies in the initial state.

\begin{tabular}{|c|c|c|c|}
\hline & Building A & Building B & Building C \\
\hline Construction period & $>1940$ & 1941-1970 & 1971-1980 \\
\hline Share in national public building stock & $15 \%$ & $28 \%$ & $24 \%$ \\
\hline Share of public buildings in EMIS database & $24 \%$ & $29 \%$ & $17 \%$ \\
\hline Geometry & & Buildings $\mathrm{A}, \mathrm{B}, \mathrm{C}$ & \\
\hline$A_{k}\left(m^{2}\right)$ & & 921 & \\
\hline $\mathrm{A}\left(\mathrm{m}^{2}\right)$ & & 1634 & \\
\hline$V_{e}\left(m^{3}\right)$ & & 3474 & \\
\hline No. of floors & & 3 & \\
\hline $\mathrm{f}_{0}\left(\mathrm{~m}^{-1}\right)$ & & 0.47 & \\
\hline Window to wall ratio (\%) & & 12 & \\
\hline Building envelope & Building A & Building B & Building C \\
\hline External walls, $\mathrm{U}\left(\mathrm{Wm}^{-2} \mathrm{~K}^{-1}\right)$ & 1.4 & 3.56 & 1.21 \\
\hline Floor on the ground, $\mathrm{U}\left(\mathrm{Wm}^{-2} \mathrm{~K}^{-1}\right)$ & 2.67 & 2.67 & 0.89 \\
\hline Ceiling bordering unheated attic, $\mathrm{U}\left(\mathrm{Wm}^{-2} \mathrm{~K}^{-1}\right)$ & 1.46 & 4.20 & 1.41 \\
\hline Windows, $\mathrm{U}\left(\mathrm{Wm}^{-2} \mathrm{~K}^{-1}\right)$ & 3.6 & 5.2 & 4.0 \\
\hline Airtightness, $\mathrm{n}_{50}\left(\mathrm{~h}^{-1}\right)$ & 9.69 & 9.04 & 7.45 \\
\hline
\end{tabular}

The last building, Building C, was designed to correspond to the period of construction between 1971 and 1980. This period is characterized by the modest application of thermal insulation. The analysed building envelope has a flat roof, fine-ribbed ceiling slab, floor on the ground level with $3 \mathrm{~cm}$ of thermal insulation, metal double simple glazed windows without seal, and walls made of hollow brick.

The characteristic U-values of all building elements of the three case study buildings are presented in Table 2. Throughout these periods, the general and thermal qualities of existing buildings in Croatia evolved. The thermal quality of building envelope variation was accompanied with a change in the airtightness through different periods of construction. Mean values of airtightness (n50) according to periods of construction presented by Krstić et. al. [38] were used for the definition of ventilation heat loss of the analysed buildings.

\section{Nearly Zero-Energy Building Concept: Energy Efficiency Measures}

Measures to improve energy efficiency generally lead to reductions in energy consumption and cost. Most energy-saving measures also increase the value of a building, improving the building's condition $[39,40]$. In this paper, energy efficiency measures (EEM) concerning thermal and energy features were implemented and evaluated in order to meet minimum energy performance requirements. The analysed measures refer both to the building envelope and the thermo-technical systems, with an emphasis on the improvement building envelope thermal properties. Hence, solar central heating and the hot water supply system were assumed to be the same in all three case studies when upgraded to nZEB, with the $30 \%$ integration of renewable energy sources. The main characteristics of the solar central heating and hot water supply system are presented in Table 3. Considering the fact that the largest percentage of the building envelope surface area consists of external walls [41], the thickness of the applied insulation layer was varied so that the $U$-value fulfilled the requirements of the regulations and an nZEB level was achieved. The differences among the U-values of building elements before and after renovation differed in correspondence with the period of construction and characteristic building technology. Table 3 summarizes the applied measures in all three case studies. 
Table 3. Proposed energy efficiency measures of the analysed case study buildings.

\begin{tabular}{|c|c|c|c|c|c|}
\hline & Energy Efficiency Measures (EEM) & EEM Description & $\begin{array}{l}\text { U-Value before } \\
\text { Renovation }\end{array}$ & $\begin{array}{l}\text { U-Value after } \\
\text { Renovation }\end{array}$ & $\begin{array}{l}\text { Maximum Allowed } \\
\text { U-Value }\end{array}$ \\
\hline \multirow{4}{*}{ Building A } & \multirow{4}{*}{$\begin{array}{l}\text { Thermal insulation of external wall } \\
\text { Thermal insulation of floor on the ground } \\
\text { Thermal insulation of ceiling bordering } \\
\text { unheated attic } \\
\text { Windows replacement }\end{array}$} & Mineral wool $-22 \mathrm{~cm}$ & 1.4 & 0.14 & 0.30 \\
\hline & & Mineral wool $-15 \mathrm{~cm}$ & 2.67 & 0.23 & 0.40 \\
\hline & & Mineral wool $-20 \mathrm{~cm}$ & 1.46 & 0.17 & 0.25 \\
\hline & & PVC, triple glazed & 3.6 & 0.96 & 1.6 \\
\hline \multirow{4}{*}{ Building B } & \multirow{4}{*}{$\begin{array}{l}\text { Thermal insulation of external wall } \\
\text { Thermal insulation of floor on the ground } \\
\text { Thermal insulation of ceiling bordering } \\
\text { unheated attic } \\
\text { Windows replacement }\end{array}$} & Mineral wool-24 cm & 3.56 & 0.14 & 0.30 \\
\hline & & Mineral wool $-15 \mathrm{~cm}$ & 2.67 & 0.23 & 0.40 \\
\hline & & Mineral wool $-20 \mathrm{~cm}$ & 4.2 & 0.17 & 0.25 \\
\hline & & PVC, triple glazed & 5.2 & 0.96 & 1.6 \\
\hline \multirow{9}{*}{ Building C } & Thermal insulation of external wall & Mineral wool $-16 \mathrm{~cm}$ & 1.21 & 0.18 & 0.30 \\
\hline & Thermal insulation of floor on the ground & Mineral wool $-15 \mathrm{~cm}$ & 0.89 & 0.23 & 0.40 \\
\hline & $\begin{array}{l}\text { Thermal insulation of ceiling bordering } \\
\text { unheated attic }\end{array}$ & Mineral wool-20 cm & 1.41 & 0.17 & 0.25 \\
\hline & Windows replacement & PVC, triple glazed & 4.0 & 0.96 & 1.6 \\
\hline & Thermo-technical system replacement & \multicolumn{4}{|c|}{ Buildings A, B, C } \\
\hline & $\begin{array}{l}\text { Heating and domestic hot water (DHW) } \\
\text { system }\end{array}$ & \multicolumn{4}{|c|}{ Thermal solar system with flat plate collectors and condensing boiler with buffer storage tank } \\
\hline & Heating and DHW energy source & \multicolumn{4}{|c|}{ Natural gas and renewable energy (solar) } \\
\hline & Cooling system & \multicolumn{4}{|l|}{ Local, split systems } \\
\hline & Cooling system energy source & \multicolumn{4}{|l|}{ Electricity } \\
\hline
\end{tabular}




\section{Cost Analysis}

Every investment has the goal of achieving financial and economic benefit. The economically optimal solution is the one that minimize the sum of construction and working (heating) expenses throughout the building lifetime [39]. It can be assumed that investments in energy-saving measures in buildings result in yearly savings that are constant during the building lifetime or until larger rehabilitation is necessary [39].

In order to analyse the potential of the proposed deep renovation, a financial analysis was conducted considering investment costs and savings achieved after the implementation of energy efficiency measures. For the purpose of this study, it was assumed that the renovation of buildings would be executed in one year. Hence, investment costs and savings were calculated in prices at the investment moment. The cost calculations included investment costs in energy efficiency and renewable energy measures. The cost-effectiveness of the deep renovation of public buildings into nZEB was evaluated through a payback period and simple rate of return calculation.

The payback period is defined as the time taken for the total initial investment of a product to be recovered by the total accumulated savings [42]. It is calculated as a ratio of the initial investment cost and savings cost due to reduced energy consumption after the renovation. It is usually expressed in years, representing the number of years needed to return the initial investment. Another method used to evaluate the potential of the proposed renovation was a simple rate of return, measuring the amount of cost savings expected by the proposed investment to derive the ratio or return that can be expected.

In this paper, the payback period and simple rate of return were calculated for the proposed renovation of all three case study buildings to nZEB. Before the calculation of the payback period and simple rate of return, the annual energy consumption and annual heating cost were determined for each case study before and after renovation into nZEB. The investment costs of each proposed energy efficiency measure were calculated based on the required material and quantity of work obtained from bills of quantities of various manufacturers and building contractors.

The results of the cost analysis in terms of the payback period, simple rate of return, annual energy consumption, and annual heating cost are presented in detail in the following section.

\section{Results and Discussion}

To evaluate the potential for the energy efficiency improvement of public buildings into nZEB, considering the construction period and corresponding building technology, both investment costs and energy savings were calculated for a case study of a nursing home. The values of annual energy consumption, annual greenhouse gas emissions, annual energy costs (for gas and electricity), as well as the energy class of the building were determined for all case studies before and after deep renovation into nZEB, as shown in Table 4. The quasi-steady-state method prescribed by HRN EN ISO 13790 [43] was used for the building annual energy use for space heating and cooling calculation, since the revised ISO 52016-1:2017 standard is yet to be implemented in Croatian technical standards. According to EN ISO 13790 [43], there are three different types of methods to determine heating energy demand that can be used on national level: (1) a fully prescribed monthly quasi-steady-state calculation method, (2) a fully prescribed simple hourly dynamic calculation method, and (3) calculation procedures for detailed (e.g., hourly) dynamic simulation methods. According to Croatian regulations, a monthly quasi-steady-state calculation method was used in this paper. The main inputs in this method are climate data, transmission and ventilation properties, heat gains from internal heat sources, solar properties, comfort requirements (setpoint temperatures and ventilation rates), and a description of building and building components, systems, and use data related to heating, cooling, hot water, ventilation, and lighting systems. The main and additional outputs in this method are annual energy needs for space heating and cooling, annual energy use for space heating and cooling, length of heating and cooling season (for system running hours) affecting the energy use and auxiliary energy of season-length-dependent technical building systems for heating, cooling, and ventilation, monthly values of energy needs and energy use (informative), monthly values of main elements in the energy balance (e.g., transmission, ventilation, internal heat gains, solar heat), the contribution of passive solar gains, and system losses (from heating, cooling, hot water, ventilation, and lighting systems) recovered in the building. 
Table 4. Annual energy consumption, annual energy cost, and initial investment cost for renovation into nearly zero-energy buildings (nZEB).

\begin{tabular}{|c|c|c|c|c|c|}
\hline Parameter & Before Renovation & After Renovation & $\begin{array}{c}\text { Investment } \\
\text { Cost-nZEB (€) }\end{array}$ & $\begin{array}{c}\text { Investment } \\
\text { Cost-nZEB }\left(\boldsymbol{\epsilon} / \mathrm{m}^{2}\right)\end{array}$ & $\begin{array}{c}\text { Energy Cost Savings } \\
\left(\mathfrak{\epsilon} / \mathrm{m}^{2} \mathrm{a}\right)\end{array}$ \\
\hline \multicolumn{6}{|c|}{ Building A } \\
\hline $\mathrm{E}_{\text {prim }}(\mathrm{kWh} \mathrm{a})$ & $345,754.94$ & $63,025.12$ & & & \\
\hline $\mathrm{CO}_{2}(\mathrm{~kg} \mathrm{a})$ & $67,282.96$ & $12,544.48$ & & & \\
\hline Annual energy cost $(€ a)$ & $15,202.53$ & 2630.32 & $171,808.00$ & 579.86 & 13.65 \\
\hline $\mathrm{Q}^{\prime \prime}{ }_{\mathrm{H}, \mathrm{nd}}\left(\mathrm{kWh} /\left(\mathrm{m}^{2} \mathrm{a}\right)\right) /$ Energy class & $248.81 / \mathrm{F}$ & $43.71 / \mathrm{B}$ & & & \\
\hline $\mathrm{E}_{\text {prim }}\left(\mathrm{kWh} /\left(\mathrm{m}^{2} \mathrm{a}\right)\right) /$ Energy class & $372.15 / \mathrm{D}$ & $65.68 / \mathrm{A}+$ & & & \\
\hline $\mathrm{E}_{\text {prim }}(\mathrm{kWh} \mathrm{a})$ & $555,532.14$ & $63,396.60$ & & & \\
\hline $\mathrm{CO}_{2}(\mathrm{~kg} \mathrm{a})$ & $109,646.11$ & $12,618.77$ & & & \\
\hline Energy cost $(€$ a) & $23,650.97$ & 2645.64 & $174,612.89$ & 583.24 & 22.81 \\
\hline $\mathrm{Q}^{\prime \prime}{ }_{\mathrm{H}, \mathrm{nd}}\left(\mathrm{kWh} /\left(\mathrm{m}^{2} \mathrm{a}\right)\right) /$ Energy class & $434.17 / G$ & $44.08 / \mathrm{B}$ & & & \\
\hline $\mathrm{E}_{\text {prim }}\left(\mathrm{kWh} /\left(\mathrm{m}^{2} \mathrm{a}\right)\right) /$ Energy class & $595.56 / \mathrm{F}$ & $66.06 / \mathrm{A}+$ & & & \\
\hline \multicolumn{6}{|c|}{ Building $\mathrm{C}$} \\
\hline $\mathrm{E}_{\text {prim }}(\mathrm{kWh} \mathrm{a})$ & $328,708.96$ & $63,205.08$ & & & \\
\hline $\mathrm{CO}_{2}(\mathrm{~kg} \mathrm{a})$ & $63,830.42$ & $12,581.74$ & & & \\
\hline $\mathrm{Q}^{\prime \prime}{ }_{\mathrm{H}, \mathrm{nd}}\left(\mathrm{kWh} /\left(\mathrm{m}^{2} \mathrm{a}\right)\right) /$ Energy class & $233.61 / \mathrm{F}$ & $45.55 / \mathrm{B}$ & & & \\
\hline $\mathrm{E}_{\text {prim }}\left(\mathrm{kWh} /\left(\mathrm{m}^{2} \mathrm{a}\right)\right) /$ Energy class & $353.48 / \mathrm{D}$ & $65.74 / \mathrm{A}+$ & & & \\
\hline
\end{tabular}


In Croatia, the energy class of a building is an indicator of the specific annual heat energy required for heating for the reference climatic data and specific annual primary energy for the reference climatic data. Primary energy factors fixed at 1.095 for gas and 1.614 for electricity were used for the calculation of primary energy and annual $\mathrm{CO}_{2}$ emissions for the purpose of calculating the energy performance of the case study building [44]. The energy price used for the purpose of calculating the energy savings was $0.43 € / \mathrm{m}^{3}$ for gas and $0.11 € / \mathrm{kWh}$ for electricity, calculated using the Croatian National Bank exchange rate list on 4 December 2018.

Keeping in mind that buildings differ in construction period and hence in construction technology, the results show that the highest energy demand and investment cost correspond to the period of construction between 1971 and 1980. This is a period characterized by the poorest thermal performance, i.e., the highest U-values of building elements. However, this period also shows the highest improvement in terms of energy savings for the negligibly higher initial investment costs compared to Buildings A and C (Table 4). The investment costs were estimated to be $569.73 € / \mathrm{m}^{2}$ for the deep renovation of Building C, $579.86 € / \mathrm{m}^{2}$ for Building A, and $583.24 € / \mathrm{m}^{2}$ for Building B. As can be seen, the results for all three buildings were close in term of investment costs.

Once savings and investment cost were determined, the simple payback period and simple rate of return were calculated for each building and all proposed EEMs (Table 5). The analysis shows that buildings constructed between 1970 and 1980 also show the lowest payback period and highest simple rate of return.

Table 5. Simple payback period and simple rate of return of the investment.

\begin{tabular}{ccc}
\hline Case Study & Payback Period (Years) & Simple Rate of Return \\
\hline Building A & 13.7 & $7 \%$ \\
Building B & 8.3 & $12 \%$ \\
Building C & 13.8 & $7 \%$ \\
\hline
\end{tabular}

The range of energy savings for the three case studies is shown in Figure 3. For Building A, energy needs decreased by around $82 \%$, for Building B around $89 \%$, and for Building C around $81 \%$ after the renovation. In terms of building age, the service life of characteristic building materials for each period was observed, taking into account the payback period for the total initial investment. The service life of 90 years for brick wall (characteristic of the first period of construction) and hollow brick (characteristic of the third period of construction), and of 70 years for reinforced concrete (characteristic of the second period of construction), was compared to the building age at the moment of the return of investment (Figure 3) [45]. Considering the construction period range, the minimum and maximum possible age of buildings after the payback period are shown in Figure 3. For the first period of construction, only the minimum age was calculated, which corresponds to the year of construction of 1940 since this minimum already exceeds the service life of material used for building construction. It can be seen that the age of all buildings from the first period of construction after the return of investment will be higher than the predicted service life; the same refers to buildings constructed before 1956 in the second construction period. Therefore, a more comprehensive approach should be applied when considering the energy renovation of existing building stock into nZEB since some buildings are very old and require substantial reconstruction aside from the improvement of thermal properties, which can make the feasibility of energy renovation questionable. 


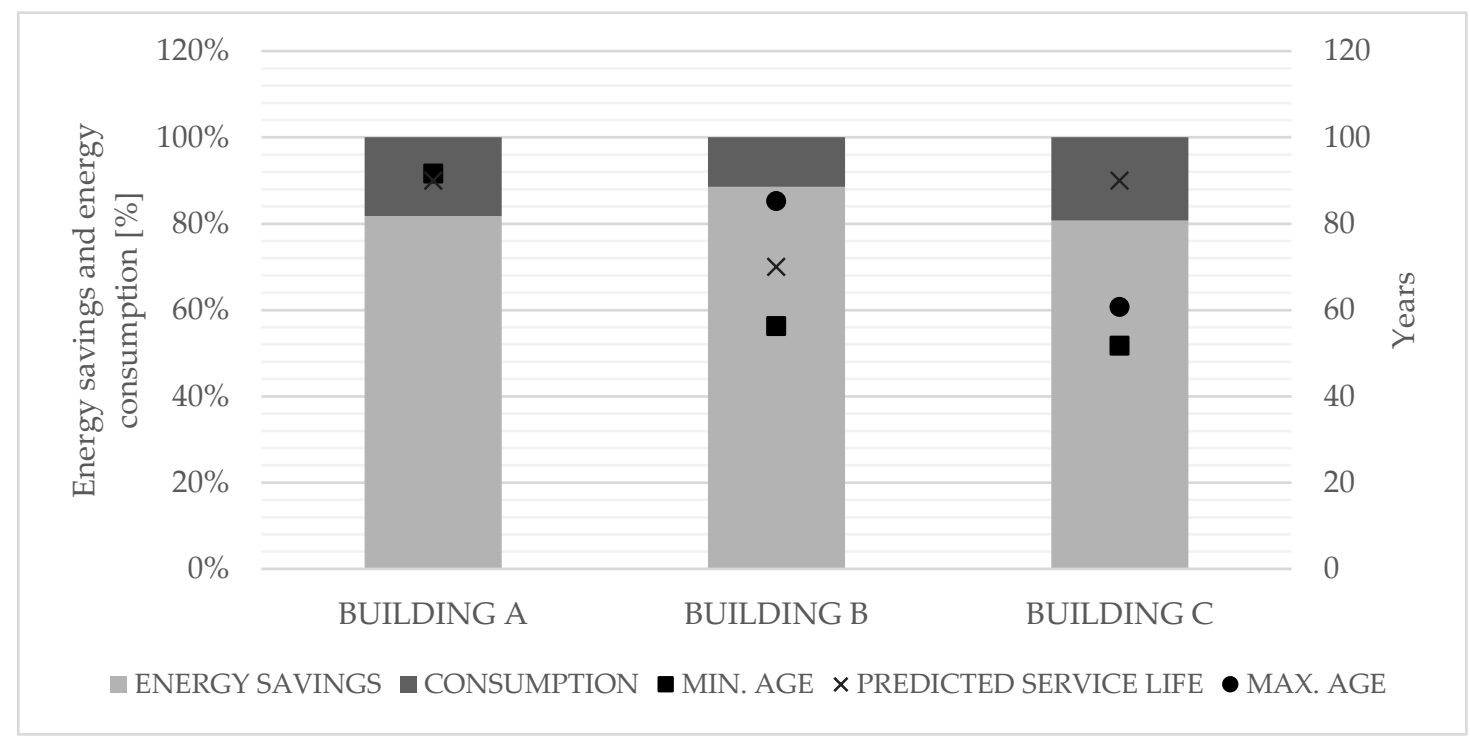

Figure 3. The range of energy savings and predicted service life.

\section{Conclusions}

This study presents the potential for energy efficiency improvement in public sector buildings in Croatia in order to achieve nearly zero-energy buildings. Energy performance and cost analyses, taking into consideration building age, service life, energy performance, and payback period, provide insight into the reduction of heat energy demands and the reduction of $\mathrm{CO}_{2}$ emissions for buildings characteristic of different periods of construction.

Existing buildings vary considerably in the thermal quality of the building envelope erected in different construction periods. The results show that the construction technology applied in different construction periods has the greatest impact on the energy performance of a building, and thus on the economic and financial viability of investment in energy renovations. The highest energy demand and investment cost, as well as the highest energy savings, correspond to the period of construction between 1971 and 1980. This period is characterized by the poorest thermal performance and the highest U-values of building elements. The results of the cost analysis, taking into account building age, show that buildings constructed before 1956 after the return of investment will be older than the predicted service life. Therefore, a more comprehensive approach should be applied when considering the energy renovation of existing building stock into nZEB, since some buildings are very old and require substantial reconstruction aside from the improvement of thermal properties, making the feasibility of energy renovation questionable. Taking into account the presented rough estimate of the size and cost of renovating existing public buildings into $\mathrm{nZEB}$, it can be seen that financing will play an important role in determining the rate of renovation to transform the existing building sector into nZEB.

While this paper contributes to the research regarding the renovation and transformation of existing buildings into nZEB, as well as the related costs and benefits, we also acknowledge some limitations. The number of valid samples used in this research from the EMIS database varied due to user negligence and lack of technical knowledge. Additionally, the characteristic U-values used for the building energy performance analysis were assumed to be the same as the characteristic U-values of building elements defined at the national level.

Future research may, however, attempt to address the above limitations by using data from various database sources. Further, a comparison of the investment cost generated by the construction of new buildings with the investment cost of the deep renovation of existing buildings towards nZEB should also be considered, together with environmental impacts, by using the life-cycle assessment method. 
Funding: This research received no external funding.

Acknowledgments: This work was supported by Croatian Science Foundation under Grant No. IP-2016-06-8350

“Methodological Framework for Efficient Energy Management by Intelligent Data Analytics" (MERIDA).

Conflicts of Interest: The authors declare no conflict of interest.

\section{References}

1. Council of the European Union. Directive 2010/31 EU of the European Parliament and the Council of 19 May 2010 on the energy performance of buildings. Off. J. Eur. Union 2010, 153, 13-35.

2. European Parliament; Council of the European Union. Directive (EU) 2018/844 of the European Parliament and of the Council of 30 May 2018 amending Directive 2010/31/EU on the energy performance of buildings and Directive 2012/27/EU on energy efficiency. Off. J. Eur. Union 2018, 156, 75-91.

3. Buildings Performance Institute Europe (BPIE). $97 \%$ of Buildings in the EU Need to Be Upgraded, Factsheet; Buildings Performance Institute Europe: Brussels, Belgium, 2017.

4. Buonomano, A.; De Luca, G.; Montanaro, U.; Palombo, A. Innovative technologies for NZEBs: An energy and economic analysis tool and a case study of a non-residential building for the Mediterranean climate. Energy Build. 2016, 121, 318-343. [CrossRef]

5. Pikas, E.; Thalfeldt, M.; Kurnitski, J. Cost optimal and nearly zero energy building solutions for office buildings. Energy Build. 2014, 74, 30-42. [CrossRef]

6. Pihelo, P.; Kalamees, T.; Kuusk, K. nZEB Renovation with Prefabricated Modular Panels. Energy Procedia 2017, 132, 1006-1011. [CrossRef]

7. Liu, Z.; Liu, Y.; He, B.-J.; Xu, W.; Jin, G.; Zhang, X. Application and suitability analysis of the key technologies in nearly zero energy buildings in China. Renew. Sustain. Energy Rev. 2019, 101, 329-345. [CrossRef]

8. Paoletti, G.; Pascuas, R.P.; Pernetti, R.; Lollini, R. Nearly Zero Energy Buildings: An Overview of the Main Construction Features across Europe. Buildings 2017, 7, 43. [CrossRef]

9. D'Agostino, D.; Zangheri, P.; Castellazzi, L. Towards Nearly Zero Energy Buildings in Europe: A Focus on Retrofit in Non-Residential Buildings. Energies 2017, 10, 117. [CrossRef]

10. Tehnički Propis o Racionalnoj Uporabi Energije i Toplinskoj Zaštiti u Zgradama (Translation: Technical Regulation on the Rational Use of Energy and Thermal Insulation in Buildings). "Narodne Novine" Broj 128/15, 70/18, 73/18, 86/18. Available online: https://mgipu.gov.hr/pristup-informacijama/zakoni-i-ostalipropisi/podrucje-energetske-ucinkovitosti/3569 (accessed on 19 June 2019).

11. Wu, R.; Mavromatidis, G.; Orehounig, K.; Carmeliet, J. Multiobjective optimisation of energy systems and building envelope retrofit in a residential community. Appl. Energy 2017, 190, 634-649. [CrossRef]

12. Ma, Z.; Cooper, P.; Daly, D.; Ledo, L. Existing building retrofits: Methodology and state-of-the-art. Energy Build. 2012, 55, 889-902. [CrossRef]

13. Charisi, S. The Role of the Building Envelope in Achieving Nearly-zero Energy Buildings (nZEBs). Procedia Environ. Sci. 2017, 38, 115-120. [CrossRef]

14. D'Agostino, D.; Parker, D. Data on cost-optimal Nearly Zero Energy Buildings (NZEBs) across Europe. Data Brief. 2018, 17, 1168-1174. [CrossRef] [PubMed]

15. Ascione, F.; De Masi, R.F.; De Rossi, F.; Ruggiero, S.; Vanoli, G.P. Optimization of building envelope design for nZEBs in Mediterranean climate: Performance analysis of residential case study. Appl. Energy 2016, 183, 938-957. [CrossRef]

16. Mora, T.D.; Cappelletti, F.; Peron, F.; Romagnoni, P.; Bauman, F. Retrofit of an Historical Building toward NZEB. Energy Procedia 2015, 78, 1359-1364. [CrossRef]

17. Paduos, S.; Corrado, V. Cost-optimal approach to transform the public buildings into nZEBs: An European cross-country comparison. Energy Procedia 2017, 140, 314-324. [CrossRef]

18. Buso, T.; Becchio, C.; Corgnati, S.P. NZEB, cost- and comfort-optimal retrofit solutions for an Italian Reference Hotel. Energy Procedia 2017, 140, 217-230. [CrossRef]

19. Mora, T.D.; Righi, A.; Peron, F.; Romagnoni, P. Cost-Optimal measures for renovation of existing school buildings towards nZEB. Energy Procedia 2017, 140, 288-302. [CrossRef]

20. Corrado, V.; Ballarini, I.; Paduos, S.; Primo, E. Refurbishment of the Residential Building Stock toward the Nearly-Zero Energy Target Through the Application of the Building Typology. Energy Procedia 2016, 101, $208-215$. [CrossRef] 
21. Desogus, G.; Mura, S.; Ricciu, R. Comparing different approaches to in situ measurement of building components thermal resistance. Energy Build. 2011, 43, 2613-2620. [CrossRef]

22. Chaffar, K.; Chauchois, A.; Defer, D.; Zalewski, L. Thermal characterization of homogeneous walls using inverse method. Energy Build. 2014, 78, 248-255. [CrossRef]

23. Ficco, G.; Iannetta, F.; Ianniello, E.; Alfano, F.R.D.; Dell'Isola, M. U-value in situ measurement for energy diagnosis of existing buildings. Energy Build. 2015, 104, 108-121. [CrossRef]

24. Sunikka-Blank, M.; Galvin, R. Introducing the prebound effect: The gap between performance and actual energy consumption. Build. Res. Inf. 2012, 40, 260-273. [CrossRef]

25. Pisello, A.L.; Asdrubali, F. Human-based energy retrofits in residential buildings: A cost-effective alternative to traditional physical strategies. Appl. Energy 2014, 133, 224-235. [CrossRef]

26. Lakeridou, M.; Ucci, M.; Marmot, A. Imposing limits on summer set-points in UK air-conditioned offices: A survey of facility managers. Energy Policy 2014, 75, 354-368. [CrossRef]

27. Barbosa, J.D.; Azar, E. Modeling and implementing human-based energy retrofits in a green building in desert climate. Energy Build. 2018, 173, 71-80. [CrossRef]

28. Papadopoulos, S.; Kontokosta, C.E.; Vlachokostas, A.; Azar, E. Rethinking HVAC temperature setpoints in commercial buildings: The potential for zero-cost energy savings and comfort improvement in different climates. Build. Environ. 2019, 155, 350-359. [CrossRef]

29. Ghahramani, A.; Zhang, K.; Dutta, K.; Yang, Z.; Becerik-Gerber, B. Energy savings from temperature setpoints and deadband: Quantifying the influence of building and system properties on savings. Appl. Energy 2016, 165, 930-942. [CrossRef]

30. Azar, E.; Menassa, C.C. A comprehensive framework to quantify energy savings potential from improved operations of commercial building stocks. Energy Policy 2014, 67, 459-472. [CrossRef]

31. Republic of Croatia, Ministry of Environment and Energy. Energy in Croatia 2016-Energy Institute Hrvoje Požar; Republic of Croatia, Ministry of Environment and Energy: Zagreb, Croatia, 2016.

32. Republic of Croatia, Ministry of Construction and Physical Planning. Proposal of the Long-Term Strategy for Mobilising Investment in the Renovation of the National Building Stock of the Republic of Croatia; Republic of Croatia, Ministry of Construction and Physical Planning: Zagreb, Croatia, 2014.

33. Marđetko-Škoro, N. Hrvatska i EU-Promjene u zakonodavstvu i implementacija europske direktive o energetskim svojstvima zgrada. Strojarstvo 2009, 51, 491-495.

34. Access Point Name (APN). System Structure-Energy Management Information System-EMIS. 2019. Available online: http://www.enu.fzoeu.hr/isge/struktura-isge-sustava (accessed on 28 May 2019).

35. Access Point Name (APN). Functionality_Energy Management Information System-EMIS. 2019. Available online: http://www.enu.fzoeu.hr/isge/osnovne-funkcije-isge-sustava (accessed on 28 May 2019).

36. Krstic, H.; Teni, M. Algorithm for constructional characteristics data cleansing of large-scale public buildings database. In Proceedings of the 2018 International Conference on High Performance and Optimum Design of Structures and Materials, Ljubljana, Slovenia, 11-13 July 2018.

37. Krstić, H.; Teni, M. Analysis of energy performance and buildings characteristics obtained from Croatian energy management information system. In Proceedings of the 3rd International Conference on Architecture, Materials and Construction (ICAMC 2017), Amsterdam, The Netherlands, 11-13 December 2017.

38. Krstić, H.; Koški, Ž.; Otković, I.I.; Španić, M. Application of neural networks in predicting airtightness of residential units. Energy Build. 2014, 84, 160-168. [CrossRef]

39. Tommerup, H.; Svendsen, S. Energy savings in Danish residential building stock. Energy Build. 2006, 38, 618-626. [CrossRef]

40. Mickaityte, A.; Zavadskas, E.K.; Kaklauskas, A.; Tupenaite, L. THE CONCEPT MODEL OF SUSTAINABLE BUILDINGS REFURBISHMENT. Int. J. Strat. Prop. Manag. 2008, 12, 53-68. [CrossRef]

41. Koški, Ž.; Ištoka, I.; Miličević, I. Classification of building elements as a function of air permeability measurements. Građevinar 2013, 65, 222-233.

42. Wong, I.; Eames, P.; Perera, R. A review of transparent insulation systems and the evaluation of payback period for building applications. Sol. Energy 2007, 81, 1058-1071. [CrossRef]

43. International Organization for Standardization (ISO 13790:2008). Energy Performance of Buildings-Calculation of Energy Use for Space Heating and Cooling; International Organization for Standardization: Geneva, Switzerland, 2008. 
44. Republic of Croatia. Ministry of Construction and Physical Planning. Faktori Primarne Energije/Primary Energy Factors. Available online: https://mgipu.gov.hr/UserDocsImages/dokumenti/EnergetskaUcinkovitost/ meteoroloski_podaci/FAKTORI_primarne_energije.pdf (accessed on 19 June 2019).

45. Anič, D. Planiranje Uporabnog vijeka građevine-Prijevod norma niza ISO 15686/Translation of ISO 15686 Parts—Buildings and constructed assets—Service life planning. In Građevinski Godišnjak 03/04; Hrvatski Savez Građevinskih Inženjera: Zagreb, Croatia.

(c) (1) 